instead of the shopkeeper that I am. Along this line, however, I believe lies the solution of many of the pressing economic questions of today which seem so hopelessly insoluble to many thoughtful citizens. It lies in making the products of business available at ever cheaper prices, and so permitting the great mass of the people to enjoy the full fruits of modern specialization and standardization. Mr. Ford has proved that this is not merely a philanthropic idea. The producer or the merchant who grasps the truth of this thought will in the end win a reward which is fairly his and which goes far beyond the dreams of the man who is in business for the profit alone.

One of America's foremost citizens lately said to me that in his opinion the security of the world depends in the last analysis on the way in which individuals conduct themselves. He said that the thing most needed was the will for service to the community, to the state, to the nation and to the world. Illustrating this point, he mentioned examples from his own experience showing that the progress of the world was retarded by selfishness, of which there was no better measure than the unnecessarily high prices charged for goods.

From the so-called "practical stand- point," also, I want to call attention to the fact that in these years of intense competition people are scanning prices as never before and buyers are going where they can buy the cheapest. Firms which cannot save their wastes of labor and material and meet this competition by selling cheaper and cheaper, will be forced out of business. Those that succeed will succeed on a bigger scale than ever before. They will sell greater and greater quantities with less and less expense and margin of profit on each item.

Mr. Ford has done this in his production. He has demonstrated in fact, and not merely in word, what the application of this idea does, in the case of an article which was a luxury when he took hold of it but became a necessity as he made it cheaper and cheaper. What is applicable to automobiles is applicable to any article demanded by the mass of the people.

So I say:

1. A business, in order to have the right to succeed, must be of real service to the community.

2. Real service in business consists in making or selling merchandise of reliable quality for the lowest practically possible price, provided that merchandise is made and sold under just conditions.

\title{
Campaign of the International Association of Rotary Clubs for the Writing of Codes of Standards of Practice for Each Business and Profession
}

\section{By Guy Gundaker}

Philadelphia, Pennsylvania, Chairman, Committee on Business Methods, International Association of Rotary Clubs

\footnotetext{
A ROTARY

CLUB consists of men selected from each distinct business or profession, and is organized to accomplish:

First: The betterment of the individual member.
}

Second: The betterment of the member's business, both in a practical way and in an ideal way.

Third: The betterment of the member's craft or profession as a whole.

Fourth: The betterment of the mem- 
ber's home, his town, state and country, and of society as a whole.

The Rotary Club of Chicago, Club Number One, was organized on February 23, 1905, by Paul P. Harris, a lawyer, and three Chicago business men. At the first meeting of the club, it was made a fundamental of membership that only one man would be selected from each business or professional calling. "Rotary" was chosen as the name of the new club because the members met in rotation at their various places of business.

From a nucleus of nineteen members in 1905, Rotary has grown to eighty thousand, with clubs in more than a thousand cities, embracing twenty-five countries of the world. It is an odd coincidence that, concurrent with the growth of Rotary, there has been a constantly increasing wave of public sentiment among business men, demanding a more exacting and more sensitive business conscience. Along with the development of this quickened business conscience men in various crafts began to feel the necessity for codes of standards of correct practice.

While it is apparent that the statement of standards of practice is the special province of national, provincial or state organizations of the various businesses or professions, experience has shown that these bodies are slow to act on such matters. In considering the writing of codes of standards of practice, one must remember that business men as a rule, through the very practical way in which business is conducted, are not abstract thinkers. Few business men have ever essayed to abstract the principles of correct human relations from the many concrete examples within their own experience and arrange them for the guidance of their fellows in the crafts; nor do they constantly examine their organizations to observe whether trade cus- toms of many years' standing have the warranty of being good business practice. The larger the business, and the greater the number of departments and employes, the more difficult it is to be absolutely certain that the business methods practised are above criticism. Many business men whose character and integrity are beyond reproach and who endeavor to conduct their business with regard to high standards, when inspired to careful self-examination of their current practices, pale when brought face to face with conditions in their establishments. They discover practices of the most reprehensible type, practices inherent in the usages and customs of the craft.

Codes of ethics have arisen in various ages, reflecting the ideas of scholars and philosophers. Most of these are couched in high-sounding phrases, calling men to higher ideals and higher business standards. Many of them are platitudes; many are so indefinite and general that they have no practical significance. It is not possible to practise undefined business ideals, or to strive to actualize glittering generalities. Therefore, the pressing need today is a plain statement of business rules of conduct which shall clearly define what one should do and what one should not do.

As Rotary is a cross section of the craft and professional world, and as each Rotarian has placed upon him the responsibility for doing something for the betterment of his craft, particularly stressing higher business standards, the International Association of Rotary Clubs has inaugurated a campaign for an intensive drive on the writing of codes of standards of correct practice in all crafts corresponding with the businesses or professions represented in Rotary. In organizing this campaign, Rotary made it quite clear that it was not presuming to advise the 
crafts as to their duty in regard to codes, but it did, however, insist that those Rotarians who were members of the craft should become active craftsmen, coöperating with their fellowcraftsmen in seeking the statement of standards of correct practice.

It has been noted that the time is appropriate for this codifying of standards of practice. It is doubly appropriate when there is a proximate transition from lean business to a period of great prosperity. It is far more necessary to create and instill inspiration for high business standards in prosperous times than in poor times. When there is little business and strong competition, business men feel the necessity of strict attention to details, high-class service and zealous regard for the highest ideals of business methods. On the other hand, when the sales-manager's desk is overloaded with orders, and people are clamoring for the products of his establishment, there is a tendency to laxness in the appreciation of these selfsame business virtues. Delivery of goods when convenient, substitutions, loose interpretation of specifications, sharp practices, are the concurrent results of waves of prosperity.

As an illustration of this tendency, you will recall that during the recent World War ethical business dealings were particularly noticeable by their absence. When these untoward conditions develop, craft organizations must step in and, by a carefully prepared educational campaign, seek to have their members and others avoid that which is the natural concomitant of business prosperity. Many years ago, Machiavelli said, "The end justifies the means." The Romans had an aphorism, "Let the buyer beware," and even our own Benjamin Franklin based a plea for honesty on the fact that it was "good policy." Rotary, as an institution, deprecates business practices based on such low motives and urges the necessity for higher business standards on the very elemental ground that such standards are right, and therefore binding on all business men. Rotary's part in the campaign for codes of correct practices is mainly inspirational.

In urging Rotarians to be active in inspiring all business or professional associations to prepare codes of standards of practice, the Committee on Business Methods felt that since the writing of codes was absolutely a new work for many craft associations, it was necessary to indicate the points which should be covered in the code. With this in view, each Rotary Club received the outline of a theoretical model code, so as to call the attention to all of the various relations which should be included. This statement was not haphazard, but was a deduction from a study of many codes received by the Committee prior to its campaign. It stated:

$A$ code of correct practices should include:

(a) A statement covering the personal character rules of conduct for the craftsman himself as the executive officer, if it be a corporation.

(b) Rules of conduct governing the relation of the employer with the employe (the observation of which may be the only known antidote for social unrest).

(c) Rules of conduct governing the craftsman's relations with those from whom he makes purchases.

(d) Rules of conduct governing the craftsman's relations with his fellowcraftsmen.

(e) Rules of conduct governing the craftsman's relations with professional men whose professions are interlocked with the craft; such as physicians, engineers, architects, etc.

(f) Rules of conduct respecting the 
craftsman's relations with the public, presumably his patrons, both clients and purchasers.

The underlying principle of these rules is Service, flanked by Honesty and Truth.

(g) Rules of conduct governing the making and executing of contracts, with special reference to specifications. (This is included as a special heading not only because of its importance, but to avoid splitting the topic in its phases, under four or five headings.)

(h) A statement of certain well-known violations of the code of correct practice with strong discouragement of such practices. In brief,- a statement of the "Don'ts" of business conduct.

If the craft to which Rotarians belong has no written standards of practice, Rotarians should take the lead, or support other craftsmen, in urging the appointment of a committee to prepare a code of correct practices. If the craft has a code of correct practices, and it fails to include all of the relations appropriate to a model code, Rotarians should take the lead or support others in urging its revision or amplification.

Let us consider the eight suggested topics for a model business code, and see what rules of conduct should be included under each heading. As a general proposition, "the earmarks of a worthwhile code of ethics are its definiteness and conciseness in statements. Rules of conduct must be very specific and plain spoken, and should completely cover all phases of business relations."

\section{A}

A statement covering the personal character rules of conduct for the craftsman himself or the executive officer, if it be a corporation.

The rules of conduct under this topic should present the personal and business qualifications of the craftsman who engages in a given business or pro- fession. The Oregon Code of Ethics for Journalism, approved January 14, 1921 , states among the personal qualifications: sincerity, truth, care, competency, thoroughness, justice, mercy, kindliness, moderation, and conservatism. Each qualification is taken up in detail in the code.

Business qualifications mentioned in many codes include: honor, integrity, business morality, credit standing, and knowledge of the details connected with the conduct of the business or profession.

\section{B}

Rules of conduct governing the relation of the employer with the employe (the observation of which may be the only known antidote for social unrest).

The standards of practice, under this topic, should be based on a spirit of fairness and coöperation, through friendship. Among the standards stated should be those covering: employment, wages, permanency of occupation, working conditions, training, opportunities for advancement, recreational facilities, disputes, assimilation of new employes, discharge from service, etc.

This particular topic is not well covered by any code received by the Committee on Business Methods. In one of the proposed codes, there is a statement which might be taken as typical of the rules covered under this topic: "Employes should be paid wages consistent with living conditions and the service rendered - a fair day's wage for a fair day's work. Employers should not permit the unusual employe to give more than a fair day's labor for the pay he receives." In order that rules of conduct might be suggested covering this portion of the code, an advertisement was inserted in the Rotarian, the monthly publication of Rotary, asking all readers who had established friendly, 
intimate and cordial relations with their employes, to write an article under the title, "How I Set My Own House in Order." It was believed that from such a symposium, many just and equitable standards of practice might be deduced. Many articles covering this point are now being studied by the Committee, to see if any general principles can be abstracted for the guidance of business generally.

\section{C}

Rules of conduct governing the craftsman's relations with those from whom he makes purchases.

Rules of conduct under this topic should include treatment of seller (audience, interviews, truthful statement of facts, etc.); purchasing methods; conditions of purchase (offer and tender); containers, where goods are f. o. b., etc.; whether the order is a brand order or an order based on set qualities; quantity shipments and prices.

The proposed code of the Restaurant Association will illustrate the types of rules of conduct for this section:

Courtesy should be given all salesmen or representatives inquiring for business. It is thoroughly good conduct to decline to see salesmen who desire to present subjects of no interest to the purchaser.

The time of salesmen should not be heedlessly wasted in having and completing interviews.

Truth and honesty should be observed in all interviews. No misleading statements should be made to secure lower prices, nor should lower prices of competitive firms be shown to others.

The seller who offers a lower price for equal quantity and quality should get the business; it should not be given to his competitor at the same figure.

It is thoroughly ethical to decline to accept goods delayed in delivery beyond the time specified, provided that acceptance would cause loss to the purchaser. It is unethical to decline goods on delayed delivery to secure price revision, if no loss has resulted from such delay.

The terms of payment governing the purchase and the place of free delivery should be fixed at the time the purchase is made, and carried out to the letter. Discounts for cash can only be taken if payment is made within the time limit specified. Etc., etc.

Note how plain-stated the code is. No indefiniteness, no frills, just a business man's writing down of his standards expressed in "Do's and Don'ts."

\section{D}

Rules of conduct governing the craftsman's relations with his fellow craftsmen.

The standards of practice under this topic are based on the principle that fellow craftsmen should work together for the benefit of each and all.

As illustrative rules, note the following:

From the Pharmacists' Code:

He should not in any way discredit the standing of other pharmacists in the minds of either physicians or laymen. He should not obtain or use private formulas of another, nor should he imitate or use another's preparations, labels or special forms of advertising. He should not fill orders or prescriptions which come to him by mistake.

From the Code of the National Association of Ice Cream Manufacturers:

Making false or disparaging statements, either written or oral, or circulating harmful rumors respecting a competitor's product, selling price, business, financial or personal standing, is an unfair practice.

Simulating in one's own product the trademark, trade name, cartons, slogans, advertising matter or appearance of the competitor's products is an unfair practice. 
As a limiting standard of practice on the relation between fellow craftsmen, the Associated General Contractors of America state:

It is improper practice to engage in or countenance any combination whereby prices are fixed or the market controlled in favor of any particular interest or against the interests of the public.

\section{E}

Rules of conduct governing the craftsman's relations with professional men whose professions are interlocked with the craft; such as physicians, engineers, architects, etc.

The interlocking relations of businesses with professions require a statement which is generally quite technical in character. The Pharmacists' Code prescribes that the pharmacist should not assume any functions of the associated profession (medical), except in cases of emergency. It stresses careful and faithful preparation of the physicians' prescription and obedience to his orders relative to refilling or supplying copies of prescriptions. Whenever there is doubt as to the physician's orders, verifying information should be secured to avoid mistakes. Similar relations exist between the architect and the builder, the civil engineer and the road constructor. Rules of conduct under this topic should be included in professional codes, so that the reciprocal relation of the professional craftsman with the business craftsman will be covered.

\section{$F$}

Rules of conduct respecting the craftsman's relations with the public in general and with those who become his patrons, both clients and purchasers.

The standards of practice governing the relations of the craftsman to the purchasing public should so direct his course that every business relation and service exemplifies honorable and straightforward dealings. This applies particularly to clients and the purchasing public. There is still another phase of the craftsman's relations to the public, treating of his conduct as affecting the general weal.

As regards the purchasing public and clients, the standards of conduct should cover fair prices, service, honest products truthfully represented, and physical equipment of the plant. The following well illustrate:

From the National Retail Monument Dealers of America's code:

To have an orderly and inviting place of business, realizing that it is not only a source of satisfaction to the owner, but compels the respect of his patrons.

From the Code of Ethics of the National Hardware Association:

Price reductions by manufacturers should be passed promptly to the retail merchant, and by him to the public.

From the proposed code of the $\mathrm{Na}$ tional Restaurant Association:

Purchases of equal quantities should have equal prices.

From the Code of the National Commercial Fixtures Manufacturers' Association:

Any craftsman who authorizes an individual to solicit business and sell goods for him should see to it that the salesman is fully instructed as to the policy he should pursue on all matters covered by the Craft's code of standards of practice.

As regards the general public, standards covering the maintenance and observance of local, state and federal laws, broad principles of social service, participation in community betterment movements (civic, charitable and philanthropic), are points to be covered in the code. Such are the points illustrated in the following:

From the Titlemen's Code of Ethics: 
That every titleman should have a lively and loyal interest in all that relates to the civic welfare of his community and should join and support the local, civic and commercial bodies.

From the Code of the Wholesale Growers of the United States:

To assist in the enactment, maintenance and enforcement of uniform Pure Food Laws which in operation deal justly and equitably with the rights and interests of the consumer, retailer, jobber and manufacturer.

From the Code of the Associated General Contractors of America:

It is improper practice to engage in any movement which is obviously contrary to law or public welfare.

From the Code of the National Association of Electrical Contractors and Dealers:

Every member of this Association should be mindful of the public welfare and should participate in those movements for public betterment in which his special training and experience qualify him to act. Every member of this Association should support all public officials and others who have charge of enforcing safe regulations in the rightful performance of their duty. He should carefully comply with all the laws and regulations touching his vocation, and if any such appear to him unwise or unfair, he should endeavor to have them altered.

Rules of conduct governing the making and executing of contracts, with special reference to specifications. (This is included as a special heading not only because of its importance, but to avoid splitting the topic in its phases under four or five headings.)

In general, the rules to be written here should have as their object the regulation of contracts between all of the parties mentioned in the code: to wit, the employer and employe, buyer and seller, the craftsman and the purchasing public, to the end that all the parties to the contract are mutually benefited. The standards under this topic should clearly state correct methods of framing specifications, definitions of the terms used, and concise expression of various trade customs and usage which constitute a large part of such specifications. In both the writing of contracts and specifications, it is necessary to devise rules of conduct to eliminate much useless legal verbiage, and particularly the avoidance of the so-called "joker clause." The latter is inserted apparently as a minor provision, but ofttimes in legal value, it outweighs in importance many of the more emphasized sections of the contract.

As an illustration the following is given from the Code of the New York Building Congress:

It is unethical for the architect and engineer to cover possible oversights and errors by indefinite clauses in contract or specifications.

A noteworthy contribution to standards of practice is supplied by the American Society for Testing Materials, which presents complete standards of practice in the making of specifications for paving brick, and rules governing their interpretation and performance. Their proposed code contains the following two paragraphs, worthy of consideration:

The contract and specifications should be drawn in plain, simple language by one who has had experience both in drawing and interpreting them.

All provisions should be fair, open and understandable without concealment, without ambiguity, without hidden meanings. Nothing should be left to inference or assumption. This will be promoted by adopting standard forms, which have been tested and proven by prior use. 


\section{H}

$A$ statement of certain well-known violations of the code of correct practices, with strong discouragement of such practices. In brief-a statement of the “Don'ts" of business conduct.

There are very few illustrations of Don'ts shown in existing or proposed codes. The "Don'ts" might be misunderstood to be the opposite rules to the "Do's" contained under all the other topics. It was not the desire or intention to have negatives developed in this way. The Don'ts were to be of a general character, or of a very broad principle. In fact, the rules to be covered could not logically be included elsewhere. The Don'ts should be ascertained by examining the three cardinal principles which have recently arisen in the business world, namely: "Let the buyer beware," "Treat the keen and confiding buyer alike," and "Truth and service-the handmaidens of business prosperity."

The National Association of Ice Cream Manufacturers includes this paragraph in its code, under the heading, "Unfair practices of sellers":

Bribery of buyers or other employes by the seller, by the payment of percentages of the purchase price of goods bought, or with gifts of money, presents, treats and so on, to obtain business or to induce continuance of business.

From the proposed Code of Ethics for Contractors (Lancaster, Pa.), may be quoted:

That a contractor cannot honorably accept a remuneration, financial or otherwise, from more than one interested party. "No man can serve two masters."

Financial or other arrangements as part of the purchase, commonly designated as graft, shall not be made. As regards the "Don'ts" covering the elimination of the corrupt and growing practice of commercial bribery, fifteen large national associations have formed commercial standards of practice. They propose to devote a vigorous attention to this topic and support national legislation for the suppression of this form of business graft. The secret giving of commissions, money, or other things of value to employes of customers, for the purpose of influencing their buying powers, is a dangerous evil more wide-spread than is acknowledged and one which is unquestionably growing.

During the month of March an intensive study was conducted by Rotary into each one of the eight suggested topics for a model code. Twenty-five district conferences were held throughout the Rotary world. Each conference was asked to discuss a single topic, in much detail. The results of this discussion will be passed to a committee for standardization and generalizing. The campaign, furthermore, was carried through the month of April in the Rotary Clubs by having Rotarians present the need for codes of standards of practice; the advantages which come to a craft through the adoption of such a code; brief experience talks by members who have been instrumental in having codes written or revised by their crafts; and talks by Rotarians before the clubs and their craft associations on the relations of employers and employes.

As regards the results of the campaign, to this point, we may summarize as follows:

1. Many men who were not members of their craft association realizing for the first time, the vital importance of such an association, in establishing higher business standards, have joined their craft associations. One national association secretary states that his association has almost doubled its membership. 
2. There are over one hundred committees at work drafting proposed codes of standards of practice. Hart Seeley, one of the district governors of Rotary, is chairman of a committee framing a code for the Glove Manufacturers' Association. The other Rotarians who are chairmen of national committees are too numerous to mention. One national secretary writes, "My office has been swamped with letters asking for our code of standards of correct practice. If the Rotary Committee will call off its Rotarians, we will immediately set about to write a code." Still another association writes, "It took us five years to frame our present code of standards of practice, which was made up mainly through compromises of men who did not wish the standards to be too exacting. Now, Rotarians urge us to go to the limit in making a stringent code. They are so insistent our President has appointed a re-drafting committee."

3. Many associations have had so many requests for their present code so that their membership might study it and ascertain if it was worthy, that they have been compelled to get out an entirely new edition to supply the requests. This feature of the campaign, in interesting many who heretofore had no knowledge of their craft code or no knowledge of the business standards sought, will accomplish great good for the general business world.

Rotary appreciates the opportunity of presenting this campaign to the American Academy of Political and Social Science, and trusts that its members who are more skilled in matters of this sort, will aid the businessman wherever opportunity offers. 